\title{
THE ROLE OF FOOD \\ IN RE-IMAGINING THE CITY
}

\section{From the neighbourhood to the region}

Teresa MARAT-MENDES, Instituto Universitário de Lisboa - ISCTE-IUL, DINÂMIA'CET-IUL; Portugal

João CUNHA BORGES, Instituto Universitário de Lisboa - ISCTE-IUL, DINÂMIA'CET-IUL;

Portugal

\begin{abstract}
Humanity is now believed to live in a new geological epoch, the Anthropocene, as changes have been reported on the atmosphere, air, water, and soil, but also on societal perceptions of these issues. This presentation departs from the theoretical assumption that the impact of the abovementioned changes on culture and the environment have not yet found a stable influence on urban planning. This presentation overviews the implications of the food system within urban planning while considering it as a socio-technical system which integrates production, distribution, transformation, consumption and disposal patterns. The production phase of the food system in particular, emerges as a fundamental planning challenge, extending to urban form solutions, individual behaviours, dietary regimes, inequalities in foodsheds planning, and the cultural capital of food. Accordingly, the food system emerges here as an opportunity to identify how current urban fabrics of cities and their rural and regional hinterlands can be transformed in terms of their metabolic function and respond to the needs of people and the environment. To do so, this presentation introduces the preliminary results of an analysis conducted by an ongoing research project SPLACH - Spatial Planning for Change, at two particular scales: the region and the neighbourhood. Thus, while focusing in the Lisbon Metropolitan Area (LMA), in Portugal, we provide an analysis of the Regional Plan as well as of specific residential neighbourhoods located in LMA, regarding the relationship between the food system functioning and urban planning approaches. The analysis includes a comparative number of case studies which differ in urban form solutions, socio-economic conditions, but also geographical location. The results support the request for a stronger integration of the above-identified underexplored topics of the food system within urban planning, which will be fundamental to inform a new theory of the city that makes any serious contribution towards a sustainability transition.
\end{abstract}

\section{Keywords}

Urban Planning, Urban Agriculture, Sustainability Transition, Region, Neighbourhood 


\section{Introduction}

Planning for a sustainable humanized environment requires the equilibrium between the social, the economic but also the physical systems. At a time when $55 \%$ of world population lives in urban areas and is expected to increase to $68 \%$ by 2050 (UN, 2015, 2016), it is important to disclose how cities socio-metabolism behave today accordingly and could be changed into a sustainable one.

Urban metabolism was first explored by Wolman (1965) who proposed to quantify the flows and stocks of materials and energy in given environments, thus understanding the city as a functioning organism. Later, advancing towards a different concept, that of socio-ecological metabolism, the work of the Vienna School of Social Ecology articulated the physical analysis of materials and energy with social activities, amounting to couple the socio-ecological systems (Fischer-Kowalski and Weisz, 2016). This approach allowed, among other possibilities, significant contributions on the transition processes between different metabolic eras (Krausmann et al, 2016) as well as on the deepening the environmental history of particular places (Winiwarter et al, 2016).

In the planning sphere, the metabolism would be acknowledged through its Circular perspective, while making effective use of waste, which was then regarded as a fundamental goal for urbanism (Rogers, 1997). The notion of Circular Metabolism would gain greater attention by academics, and the urban system was expected to work while making use of its own waste. However, this call for circular metabolism of cities found a difficult relationship with current planning in many countries. In some cases, this tension reveals the limitations of planning structures focused on 'management' rather than 'planning', which ensure relative liberty for urban development projects on the private sector, but often delay the necessary transition of urban systems to more sustainable models.

The project 'SPLACH - Spatial Planning for Change' aims to inform future public policies for such transition to sustainability, including the fundamental role of urban socio-ecological metabolism while reinforcing its spatial dimension, through the understanding of its implications on urban form. The research team of DINÂMIA'CET-IUL for SPLACH project is focusing its analysis on Lisbon Metropolitan Area (LMA), which includes 18 municipalities and is the most densely populated metropolitan area in Portugal.

Fundamental for an effective metabolism is the access to basic human needs, which all cities must ensure in order to be liveable: housing, water, electricity, transportation, internet and food. While some of these are widely acknowledged in Portuguese planning instruments, others, particularly water and food, are relatively absent.

The food system - the pattern across which food is produced, transformed, distributed, commercialized, consumed and disposed (Pothukuchi and Kaufman, 2000; Steel, 2008) - has inherent spatial implications, as it relates to land-use systems, infrastructure and both the built and natural environments of cities.

Although some studies have been developed to diagnose the LMA food system and its metabolic impact (Oliveira et al, 2017) this is still not reflected in the central documents of spatial planning in Portugal - the municipal Masterplans, as well as on urban design scale. Although some Portuguese municipalities have ventured into food-related programs, including refurbishing of municipal markets, urban allotment gardens and pedagogical farms, these are not yet included in the general strategies for the development of LMA municipalities (Cabannes and Raposo, 2013; Oliveira et al, 2017; Marat-Mendes et al, 2018). 
On the other hand, many grassroots initiatives can be observed in the actual territory that are also invisible in planning documents, and which seem to have deserved little attention or interest from planners. Initiatives of urban agriculture have been subsidized by municipalities in the LMA, but these municipal programs are very different from Guerrilla Gardens in many of the same municipalities, which attest to how communities have appropriated vacant and even private spaces for food-production purposes. Nevertheless, it should be noted that such grassroots initiatives have already received the attention of a number of researchers, former members of FAO and UN organizations, such as Cabannes and Raposo (2013)

This paper aims to observe 'invisible' food-related initiatives, particularly at the production phase of the food system, emphasizing the potential role of urban agriculture in improving the socio-ecological metabolism of the LMA, and confronting it with the approach to the territory comprised in spatial planning. Two planning scales will be central here: the regional and the municipal. The former allows an observation of how the territory of the LMA is envisioned in public policy, while the latter allows a more direct confrontation between particular places and their treatment in planning, inclunding the design solutions which have guided them.

\subsection{Literature review}

The study of the relation between the food system and urban planning has deserved greater attention in recent years. A succinct description of the food system would present it as the system of activities across which food is produced, processed, distributed, cooked, eaten and disposed of (Pothukuchi, Kaufman, 2000; Steel, 2008). This includes not only the activities themselves but also the institutions (Pothukuchi, Kaufman, 2000) and the power relations (Wekerle, Classens, 2015) implicated in those activities.

Although nearly two decades ago, Pothukuchi and Kaufman (2000) presented the food system as a 'stranger' to the planning field, this situation seems to have changed meanwhile. Brinkley (2013) comprehensive account about the research in this area, concludes that most aspects of the food system have already entered into the concerns of urban planning studies, while emphasizing that the waste-disposal phase of the system, as well as the cultural capital of food remain however underexplored. Steel (2008) analysed the relations between food production and the structure and distribution of activities in specific cities, while Parham (2016) explored the role of food in relations of urban conviviality and concluded that this plays a fundamental role in a future sustainable development.

Notably, most authors interpret the food system as a holistic and multi-scale system, which comprise aspects related to the political economy, public health, environmental impact and cultural issues (Reynolds, 2009; Steel, 2008; Viljoen and Bohn, 2012; Reisch et al, 2013; Brinkley, 2013; Cohen and Ilieva, 2015; Sonnino, 2019). Reisch et al (2013) have used the term 'integrative paradigm' to define an adequate methodology towards the food system. This entails creating integrative, cross-sectoral, population-wide food policies extending to the entire food system in order to ensure its overall sustainability.

However, this definition is already enough to point out some problems arising from the food system and its study. One major problem has to do with the fact that the food industry is highly fragmented (Reisch et al, 2013) with inquiries usually struggling to establish interdisciplinary links between fields of study and planning (Brinkley, 2013). This problem applies not only to the urban food system, but to the urban systems in general, particularly with 
respect to sustainability issues (Webb et al, 2018). Analysing urban systems - including the food system - for their institutional role will then imply accepting that not only policies are fragmented, but also that several institutional forces may prove to be a barrier to integrated and large-scale change (Webb et al, 2018).

In a sense, this situation may be specific of our times, as neoliberalism, social inequality, the domain of the private market over cities (Drago, 2018) and sustainability threats (Cohen and Ilieva, 2015; Fischer-Kowalski and Weisz, 2016) call into question the institutional structures and power distribution underlying urban systems. With respect to the importance of neoliberal economics in the food system, Steel (2013:59) points out that agribusiness has created a situation in which food supplies are determined not by local cultures but by economies of scale. More recent accounts (Sonnino, 2019) have emphasized a shift of food system approach with public entities increasingly acknowledging their own participation as actors in the food system.

As such, we may accept that ours is a time when we have outgrown the institutions we have and are struggling to design new ones (Bartlett, 2017, p.194). As such, urban systems insofar as they are deeply implicated in the division of society in space - and food systems as they ensure a human basic need - may provide the basis for new conceptual frameworks which allow us to imagine different institutions able to respond more effectively and closely to the population and environment demands, across a variety of scales of space and governance (Webb et al, 2017:69).

The relation of this with urban form is also a critical point for the food system, although in many papers, the spatial dimension is under-stressed or even entirely overlooked. Urban form, understood as the configuration of fixed metropolitan elements, comprises several important features of cities, including density, compactness and land-use (Lo, 2016), the importance of which is very considerable within the food system.

With respect to urban agriculture, and specifically to the practices of guerrilla gardening, Richard Reynolds' handbook 'On Guerrilla Gardening - A hand book for gardening without boundaries' (2008) presents an overview of this movement, as well as several important notions - both theoretical and practical - of these illegal proactive actions.

Although urban agriculture is also being studied by itself as a social and even political movement, there are many reasons why it would be so stressed in food system literature. One important aspect is that the production phase of the food system is where most environmental implications are located, including land-use, soil degradation, water consumption and pollution, eutrophication, biodiversity loss, and introduction of hazardous chemicals (Reisch et al, 2013). Furthermore, it is also at the production phase of the food system where most of the financial implications are located, in particular in what concerns the land which is needs for such activity. This is mostly depended on land values which greatly depends on the speculative market.

On the other hand, industrial agriculture itself is a problem in terms of metabolism, as it is mostly dependant on non-renewable energy sources (Erb et al, 2016) with deep implication in Net Primary Production - energy fixed by autotrophic organisms - which is at the basis of heterotrophic food chains and accumulation of carbon stocks in soil (Erb et al, 2016). Discussions of urban agriculture are usually considered for themselves, with livestock being usually left out of any perspective for urban space (Reish et al, 2013; Brinkley, 2013). Furthermore, the general absence of the food system and urban agriculture from urban land 
physically segregates consumption from production, leaving populations dependent on private-market food-outlets, and often adding to other social problems of poverty and access to land or housing (Purcell and Tyman, 2015; Cabannes and Raposo, 2013; Wekerle and Classens, 2015).

Moreover, from the perspective of labour challenges, since the 1970s, agricultural labour has been decreasing, to the point of near disappearance (Fischer-Kowalski, Haas, 2014). And with respect to architecture and urban planning, Viljoen and Bohn (2012) advance a new model for sustainable urbanism which prioritizes the creation of a 'productive multifunctional landscape' with spatial, social and environmental implications.

\subsection{Methodology and structure of the article}

This paper aims to clarify the important role which urban agriculture plays within the LMA. To do so, it confronts some of the problems stated in the Municipal Plans of the municipalities of LMA with actual initiatives that can be found on the territory. Our present analysis focus on three specific municipalities of LMA, namely Lisbon, Oeiras and Almada. For each municipality, we will analyse a specific urban agriculture initiative and identify what particular contributions they may provide for both improvement of urban structure and of urban socio-metabolism.

To do so, this paper is divided in four parts. After this introduction, section 2 presents a brief overview of Portuguese spatial planning, specifying the roles of the municipal and regional scales and observing how the food system is or is not present at these planning scales. The third section details the case-study of urban agriculture, confronting initiatives with spatial plans, but also with the issues identified in the above literature review. Section 4 includes the concluding remarks, as well as suggestions for how to acknowledge and incentivize the already existing initiatives analysed in the previous section.

\section{Urban planning in Portugal}

The current structure of spatial planning in Portugal has been fundamentally determined since the 1974 Revolution which overthrew a conservative dictatorship that had been in power since 1933. However, municipalities under the dictatorship had also produced spatial planning documents.

After the Revolution, the 1982 Law of Soils attributed to municipalities responsibility over their spatial planning, and two further Ground-Basis Laws for Spatial Planning were issued since, in 1998 and 2014. Within the structure of Portuguese spatial planning, the municipal level has a singular importance, since it is mandatory for each municipality to have an approved Municipal Plan, a Plano Director Municipal (PDM). This has been required since the first Portuguese Law of Soils was published in 1982. Since then, other planning scales such as the National, Regional, Intermunicipal and Interregional are also foreseen within the Ground Basis Law for Spatial Planning, but their preparation of approval is not systematic and sometimes are never fulfilled.

\subsection{The Lisbon Metropolitan Area and its food system}

The territory of the LMA comprises 18 municipalities - Mafra, Vila Franca de Xira, Sintra, Amadora, Lisbon, Odivelas, Loures, Oeiras and Cascais in the Northern Bank of Tagus river and Almada, Barreiro, Alcochete, Sesimbra, Seixal, Moita, Palmela, Setúbal and Montijo in 
the Southern Bank of Tagus river. The Metropolitan Area is an administrative delimitation which was established in the early 1990s, extending for the Lisbon Region. Together, these municipalities totalize $3015,24 \mathrm{~km}^{2}$ and are home to 2812678 people, amounting to a population density of $935,8 \mathrm{hab} / \mathrm{km}^{2}$. The Ground-Basis Law on Spatial Planning determines which soils must be classified as urban but also those that are rural. From the 18 municipalities of LMA, 17 include those both classifications of soil, while the Lisbon municipality comprises only the urban one.

In the transition from the $19^{\text {th }}$ to the $20^{\text {th }}$ century, the Lisbon municipality concentrated more than half of the population of the Lisbon Region, and at least $40 \%$ of its territory was agrarian, while the built environment amounted to only $16 \%$ (Niza et al, 2016). This territorial organization was not symmetrical to the social division of labour, as only $4 \%$ of the Lisbon population worked in agriculture, versus $17,3 \%$ who worked industrial jobs, and only $1 \%$ of Lisbon's food was produced within the city (Niza et al, 2016). Cereals, wine and olive oil, all important foodstaples of the Mediterranean diet, were all brought into the Portuguese capital from its surrounding municipalities (Niza et al, 2016). Also, within the Lisbon Region, about 1000 farms and about 200 gardens ensured the production of fruit and vegetables (Marat-Mendes et al, 2015).

The formation of the Municipal Plans dates back to the 1930s, when the Portuguese Government ordered new General Plans of Urbanization to organize the growth of cities with more than 2500 inhabitants. Nevertheless, a number of cities under such conditions, never witnessed the development of their plans. Furthermore, some regional plans would soon be drawn but not approved. A particularly important exception was the Plano de Urbanização da Costa do Sol (PUCS), a sub-regional plan which sought to develop the urban planning of the coast area located between Lisbon and Cascais. The PUCS infrastructure was designed by the French urbanist Alfred-Donat Agache in 1935-1936, including the first motorway built in Portugal, but it was Étienne de Gröer who would conclude the PUCS and design the Urban Plans for the urban centres along Costa do Sol, which would be concluded in 1946 and approved by the Portuguese Government in 1948 (Marat-Mendes, 2009). The PUCS remained active until the early 1990s (Pereira, 2009).

The strong relation between Lisbon and the remaining municipalities through the food distribution was indirectly acknowledged in the plans by Étienne de Gröer, within PUCS in particularly, at the neighbourhood scale, where Gröer applied the Garden City principles as proposed in England by the social reformer Ebenezer Howard (1902). The PUCS included urban settlements separated by rural belts, which included gardens and farms, all linked through a three-layered mobility system with motorway, highway and train (Marat-Mendes, 2009). Moreover, in his Masterplan for Lisbon, the Plano Director de Urbanização da Cidade de Lisboa (PDUCL), Gröer predicted the construction of council housing neighbourhoods, all designed by other architects and mostly inspired by the Garden City, but also by the Garden Suburbs designed by Raymond Unwin. In these Lisbon neighbourhoods, the preferred building type was the single-family detached house with a small front-lawn and a larger backyard meant for leisure and food-production (Marat-Mendes and Borges, 2019).

Although the PDUCL failed to be approved by the Portuguese Central State, a new Masterplan was prepared but also shared its unapproved fate. Such situation left Lisbon without an overall Planning instrument and driven by sporadic urban plans, for specific delimited isolated areas would govern Lisbon urban growth in a random manner (Marat- 
Mendes and Borges, 2019). In the case of Lisbon, the 1950s and 1960s are a period of legal void in terms of planning, and the plans for further council housing start embracing the need for construction at a greater scale and with greater density. To this period correspond the urbanization plans for the Olivais area and for the Chelas Valley, both large-scale agrarian zones, converted into urbanized land (Marat-Mendes and Borges, 2019). Although all urbanization plans predicted the creation of green areas, these did not respond to any productive proposes, as they meant especially for landscaping and leisure of communities.

In the transition from the $20^{\text {th }}$ to the $21^{\text {st }}$ century, this situation changed dramatically, with a very significative increase of the urbanized land. This is closely related to the post-Revolution spatial planning structure, which established municipal planning, but left unresolved tensions between land-use regulations and private property rights (Mourão and MaratMendes, 2016). This has led to massive - and often unplanned - land-use conversions which translated into a significant loss of rural soils and a construction boom that eventually led to housing surplus and uncontrolled speculation (Mourão and Marat-Mendes, 2016). However, the LMA still comprises a significant amount of rural soil, and 740000 tons of foodstuff were produced within it in 2015, against 3,7 million tons which are exported from other parts of Portugal and 5,4 million tons from other countries, mostly in Europe (Niza, 2017). To this, one may add that the LMA exports 4,7 million tons of foodstuffs for other parts of the country and 1,8 million tons for other countries (Niza, 2017). As such, the LMA is still a highly productive metropolitan area.

The dichotomy between productive and unproductive land has grown more polarized throughout, as green productive areas are classified as rural, but urban land in Lisbon can only comprise urban parks - essentially non-productive. This tendency responds to the paradigm inherent to the Ground-Basis Laws, which establish that urban land cannot be productive. As such, although urban agriculture has always existed within urban perimeters, including in Lisbon itself, its role is underacknowledged and its presence in urban planning is scant and difficult. Although most municipalities are creating urban agriculture parks, these are all small-scale and oriented towards leisure and landscaping, with few acknowledgements for its productive aspect (Marat-Mendes et al, 2018). Beyond these municipal initiatives, there are several examples of Guerrilla Gardens - both productive and unproductive gardens located in areas non designated for such activities (Reynolds, 2008) in all LMA municipalities, the majority of which differ significantly from the municipal allotment gardens both in what regards their goals but also the design, showing that the role of agriculture within the urban land of the LMA may still be greater than previously acknowledged.

\subsection{The municipal level}

The PDM coordinates two lower scales for planning purposes, namely the Urbanization Plan, Plano de Urbanização (PU) and the Detailed Plan, Plano de Pormenor (PP). These lower scales must abide by the sets and rules of the PDM and are employed regularly for several kinds of construction work.

The PDM synthesizes the economic and social strategy for the development of a municipality in their spatial dimension. As such, it defines land-use partitions, areas for special programming, infrastructures and territorial management.

Although the PDM's were of strategic importance for the urban growth of Portuguese municipalities, the evolution of their implementation proved to be a difficult task. Although 
each PDM should be rewritten every ten years, within the LMA, half of the current PDMs date back to the year 2000 and have not yet been revised. Moreover, contradictory interpretations of the relation between land-use regulations and private property have long allowed unplanned development in many Portuguese municipalities, the LMA included (Mourão and Marat-Mendes, 2016).

In spite of the Ground-Basis Law for Spatial Planning, PDMs in the LMA have been written throughout a wide timeframe, and thus they are meant to tackle local, territorial and socioeconomic problems which may have changed greatly since their writing. Eight of the 18 PDMs are prior to the first Ground Basis Law (1998), five were approved in 2015, one year after the second Ground-Basis Law, leaving however unclear which Ground Basis Law have indeed guided them. Only one PDM was approved afterwards. While all municipalities include urban land, with the exception of Lisbon municipality, all include also other classes of land ranging from 'rural land' to other specifications such as agriculture, forestry, agroforestry, green protection and natural spaces.

Our analysis of the PDM's of the Municipalities has concluded that the food system is never directly mentioned in these planning instruments, although it is often implicit on dispositions related to rural land. Notably, most PDMs include agriculture where construction is not allowed; and natural spaces are placed in urban land, but essentially as a non-productive one.

In many PDMs, urban agriculture initiatives could be incepted into programmed reconversion of industrial facilities. Urban farms or gardens are mentioned in the PDM's of Lisbon, Cascais, Odivelas and Oeiras, but their value is never acknowledged as a productive one. Instead, it is regarded as a leisure outdoor activity.

The PDM of Oeiras indicates the allocation of spaces for biomass production in its Ecological Structure. In turn, the Vila Franca de Xira PDM, allows "industrial facilities for production, transformation and commerce of produces of agriculture, livestock and forestry" in some of its agricultural spaces. Commercial activities are usually allowed in urban land and often in industrial and forestry land. However, food-commerce is not distinguished from other types, although accounting for food-outlets would help municipalities keep track of food-access (Moudon et al, 2013) and identify where deficiencies are located.

Generally, urban farms are unacknowledged as opportunities for kickstarting a local short food-supply chain. Finally, there are abundant regulations for maintaining ecological balance and controlling the effects of automobility in public space, but no attention is given to the environmental benefits that could be drawn from such public and vacant spaces.

\subsection{The regional level}

As stated above, the regional level is predicted in the Portuguese spatial planning structure, but it is not mandatory. A further difference between the PDM and the Programa Regional de Ordenamento do Território (PROT) is that the former is binding for both public and private entities, while the latter only includes public entities. The first PROT for the LMA (PROT-AML) was written in 2002, but its revision never came to be approved.

Written in the early 2000s, PROT-AML aims to give the LMA an European and Iberian capital, taking advantage of the potentials of its geographic location for Euro Atlantic business (DGT, 2002), a goal which may have been interrupted by shifting political and financial conditions within the country from 2007 on. 
The territorial strategy of the PROT-AML is based on reaffirming the central role of Lisbon within the metropolitan area, using its recently increased access to the Southern Bank of Tagus river to revitalize its critical areas. In the Northern Bank of Tagus river, the situation is more polarized, with the Amadora-Lisbon-Loures-Vila Franca de Xira belt in critical urban condition and the Lisbon-Oeiras-Cascais (former PUCS territory) in optimistic development. Extensive green areas are located in the more peripheral areas of Mafra, Sesimbra, Palmela and Montijo, countering the more densely urbanized areas (DGT, 2002). The PROT-AML also includes an Environmental Strategy, which acknowledges the quality of the metropolitan agrarian and forestry spaces, which are meant to be protected as a feature of local character against excessive urbanization or infrastructure needs (DGT, 2002). One way to ensure this protection is the Metropolitan Structure of Environmental Protection and Recovery, which must map and manage specific parts of the territory, but also promote adequate activities to integrate these areas into the remaining urban structure.

\subsection{Food and urban planning - some questions}

Despite the central importance of food in cities, its presence in spatial planning at both the regional and the municipal levels in LMA is indeed scant. Many municipalities have published specific programs which relate to the urban food system, including networks of urban allotment gardens, but these are not predicted in the PDMs and neither in the PROT for the LMA.

Given such absence, we submit that the best way to understand the role of the food system on a potential sustainable transition of the LMA territory is to ascertain how it relates to the needs and desires of local communities, many of whom have shown great resourcefulness and willingness to participate in food-production activities. Furthermore, we call for a recognition of the historical role of food in the territory and of how $20^{\text {th }}$ century planning has determined the relations between urban spaces of consumption and rural spaces of production. As this polarization between urban and rural is implied in all PDMs of the LMA, but also on its PROT, we seek to confirm if this same polarization can be confirmed in particular places.

\section{Urban agriculture}

\subsection{The Chelas Valley and the Condado Estate}

The Chelas valley area, located in the Easter area of Lisbon Municipality, comprises a total of 510 ha of a territory, which was an agrarian area until the 1960s. At this point, the acute housing shortage felt in the city led the municipality to start an urbanization plan, whose final version would be coordinated by architect Francisco Silva Dias and concluded in 1964. This plan would be subject of a revision process throughout its implementation process, yet aspects such as infrastructure and public equipment came rather late and different from what had been originally planned, thus compromising its success (Heitor, 2001). Divided into six zones (two of which were subdivided in two), only Zones I, J and N2 were implemented according to the original plan, and the first two were occupied in the aftermath of the 1974 Revolution. Most occupants were immigrants from the former Portuguese colonies in Africa, and the Democratic State came to legalize their presence. However, without predicting the difficult social conditions that would result from fundamentally poor communities, instead of the mixed communities envisioned in the urbanization plan (Heitor, 2001). 
From all the Zones in Chelas, Zone J was by far the most ill-reputed, associated with the anathemas of crime, unemployment and drug-trafficking (Heitor, 2001). The planners, Silva Dias and J.A. Lobo de Carvalho, conceived Zone J as a 'building-city', a megastructure based on a continuous plateau with services and commerce, above which housing slabs rose, designed by architects Tomás Taveira and Vítor Consiglieri. The whole estate included service areas, linked by pedestrian decks, which ensured a circulation system detached from the motorways.

Recently renamed as Condado Estate, the area underwent a rehabilitation project whose most important aspect was the demolition of the central slab in 2009. In the Chelas Valley, another important change was the creation in 2010 of the Chelas Valley Horticultural Park, which occupies an urban park between Zones N2 and N1. However, this Horticultural Park is much smaller than the large extensions of Guerrilla Gardens that remain within the Chelas territory.

The Condado Estate is surrounded by Guerrilla Gardens in its southwestern and northeastern limits. They occupy the vacant areas meant to counterbalance the high-density of the housing slabs. With plots of varying size and generally structured in a very privatized and individualized manner, most are accessible from the outside, and there is very scant use of gated shared pathways between different plots. Limits between plots are very well established, including through wooden fences and walls constituted by recycled materials. Some fruit trees are scattered on the terrain, but they are not a dominant cultivation type here. Although some of the plots are generally abandoned, most of them are still in use, and their cultivation is especially of edibles.

The Condado Estate includes some commercial areas which sell foodstuffs, and it is nearby Zone $\mathrm{O}$, which comprises the planned 'central area of equipment', also has supermarkets and other food venues. However, the Condado Estate is surrounded by large motorways with very few crossings and often without sidewalks. Pedestrian circulation is very difficult within Chelas itself, and also to the rest of the city. Moreover, given its high-density dynamics, the estate comprises a significant amount of public open space, but this is often used as parking space. Despite the presence of the gardens, and their proximity to some of the most difficult parts of the estate, urban agriculture was not contained in any rehabilitation programs. 

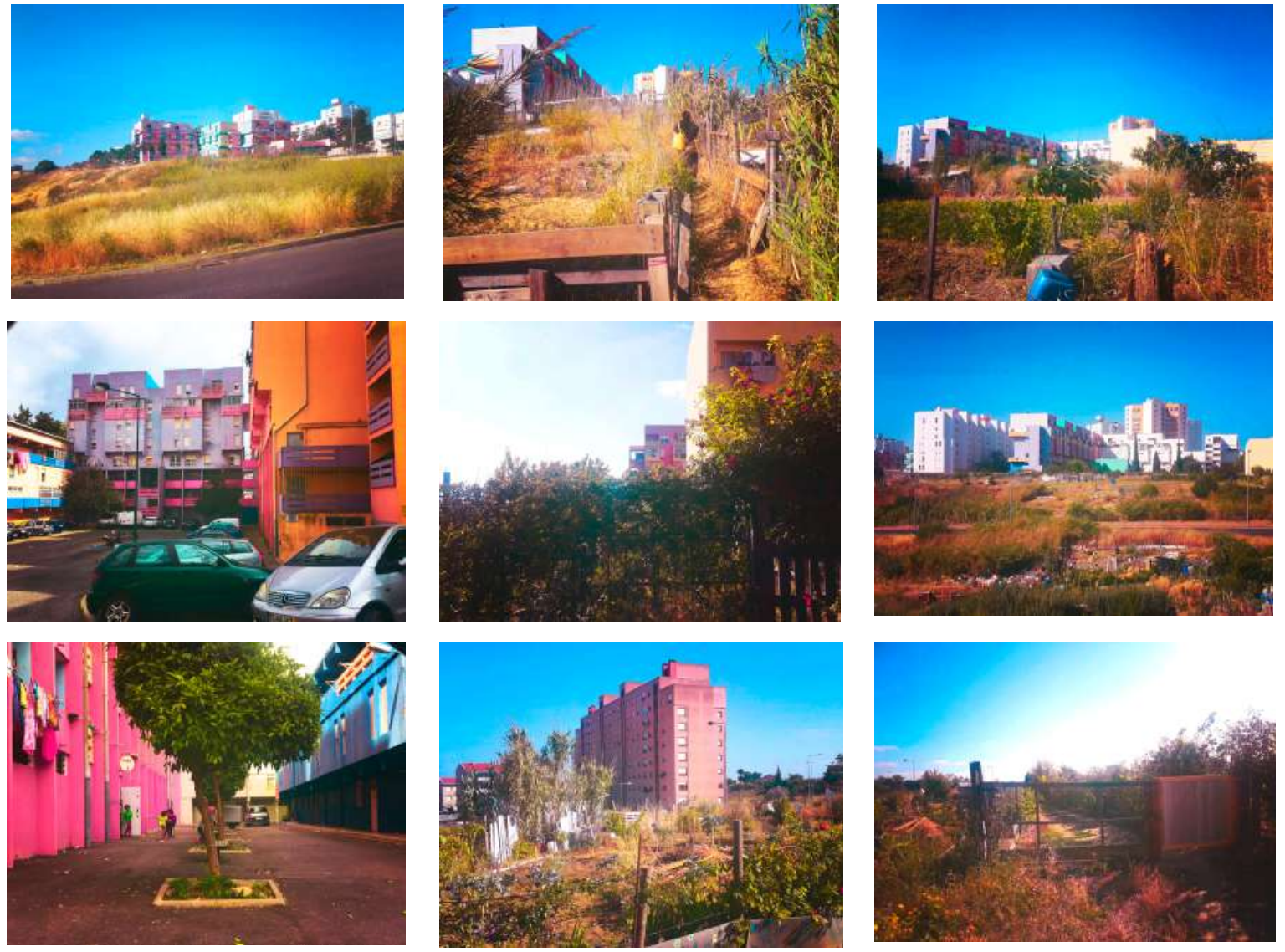

Figure 1 The Condado Estate and its surrounding Guerrilla Gardens

\subsection{Laveiras - multifunctionality, transportation}

The Laveiras Housing Estate area is located in the Municipality of Oeiras. Its design was initiated in 1987 by Architects Pedro Viana Botelho and Nuno Teotónio Pereira and its construction ending dates from 1990. Comprising fifteen housing slabs with terraces on the ground- and first-floors, this neighbourhood was further on added to another estate, a set of seven housing towers designed by other group of architects. Separating the slabs from the towers is a commercial gallery on the ground floor of the eastern limit of the original estate. The whole neighbourhood is barely accessible from its western limit, where it is limited by a motorway with no sidewalk. Indeed, the only pedestrian link between Laveiras and the Oeiras centre (on the eastern side) is a single road cutting across neighbourhoods of single detached houses. The most acute problems with the Laveiras Estate are not related to the quality of housing or public space, but rather to accessibility issues. Inhabitants have no option but to move using car or bus, which links it only to the Oeiras municipality.

Furthermore, on its eastern and western limits, Laveiras is surrounded by green or vacant areas. It was in these free areas located in the western but mostly the eastern limit of Laveiras that Guerrilla Gardens have emerged. On the eastern limit, behind the south set of towers lies and defined by Estrada de Laveiras is the second and third set of gardens. The second comprises 12 metres wide plots which run until the creek further east. Plots are explored individually by families who live in Laveiras and are all cultivated and relatively dense. Separation between plots is mostly ensured through vegetation (sugar canes in 
particular) and with reed skirting, sugar canes and assemblages of recycled wood and metal. Production is mostly for self-consumption and the land is owned by the Caxias Sports Association.

Another larger set of allotments starts behind the northern set of towers, with varied sized of plots, which are also explored by residents of Laveiras. Most plots are of rectangular form, perpendicular to the creek, but others have used the space located between the circulation pathway and the creek, which is usually narrow and long. Only a few plots are not cultivated, and most are cultivated with vegetables but also with fruit trees, especially in larger plots. Production is mostly for self-consumption and the land is privately owned and paid yearly between all the farmers/gardeners who use it.
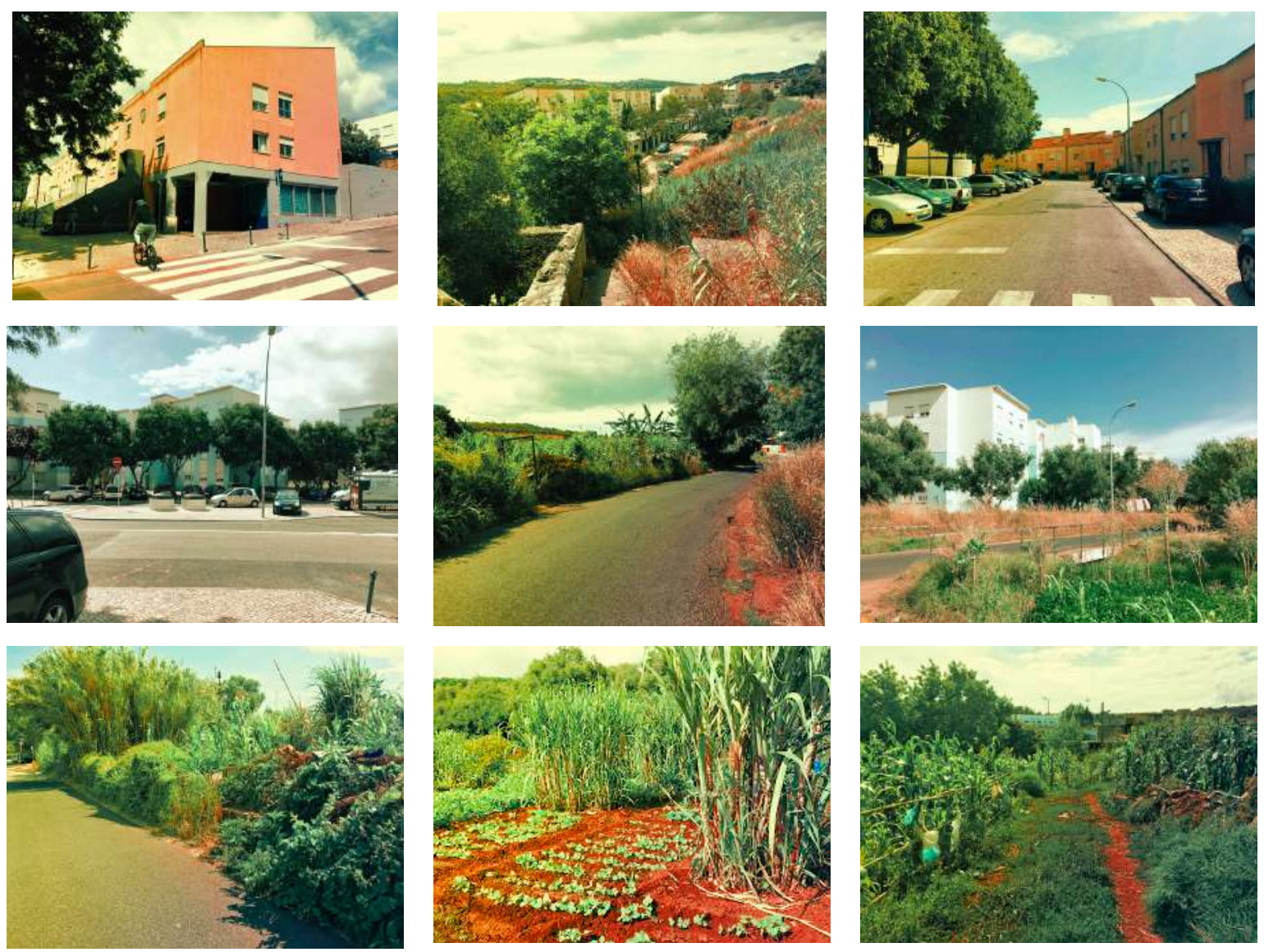

Figure 2 The Laveiras neighbourhood and its Guerrilla Gardens

\subsection{Almada - access and renovation of the ecological structure}

Almada is one of the LMA municipalities whose PDM was written prior to the Ground Basis Law, in this case in 1997. Although the next version of the PDM, which is currently under revision, is expected to devote an entire section to urban agriculture (Marat-Mendes et al, 2018), the current one does not mention urban agriculture at all. Specifically, the PDM is protective of Almada's green-fields but not attentive to agriculture.

Hortas de São João are a municipal allotment garden, implemented on land classified as channel-space for infrastructure. Around it, it has many housing blocks and detached houses 
with gardens and yards of varying size. In all cases, these buildings are privately owned, as this is not a designated area for council housing. Also nearby is a large vacant space. As such, Hortas de São João are located in a very diversified urban context, ranging from high- to lowdensity, and in proximity to commercial activities and motorways. The allotments are owned and managed by the municipality, and the access of gardeners to such allotment requires a registration for a selection process. Then, each gardener whom have been granted authorization to work the allotment will be in charge to maintain its plot. Only biological agriculture is allowed, and the municipality provides workshops to inform about it. Fruit trees are not allowed in the plots, as these provoke shades. Therefore, a specific plot is designated for the cultivation of trees of all gardeners. Most gardeners are retired or unemployed, and the park includes some convivial areas and leisure spaces, meant for activities relatively dependant on the agricultural aspect of the initiative, like barbecues and picnics.

Unlike Guerrilla Gardens analysed so far, these plots are organized according to an orthogonal grid, a standardised composition unit and a properly installed irrigation network. The proximity to some housing blocks of different scales, from towers to cottages, has no particular impact in the design, although most farmers do live nearby.

However, it must be noted that plots here have varying size, ranging from $25 \mathrm{~m} 2$ and 125 $\mathrm{m} 2$, perhaps because a lot of them are attributed not to individuals but to families (MaratMendes et al, 2018). The rental value paid for each plot depends on its size, and plots are distributed firstly between candidates with financial difficulties. But, there are waiting lists of people wanting access to a plot that the municipality has not yet been able to respond to. However, the access conditions promote food security by prioritizing those whose access to food may decrease, but also promote socioeconomic variety by placing the park close to middle-class neighbourhoods. Almada has a long history of cooperative organizations, and the Municipality was run by a communist-leaning coalition between 1976 and 2013, which may explain the sensitivity of the municipality to the social role of urban agriculture. 

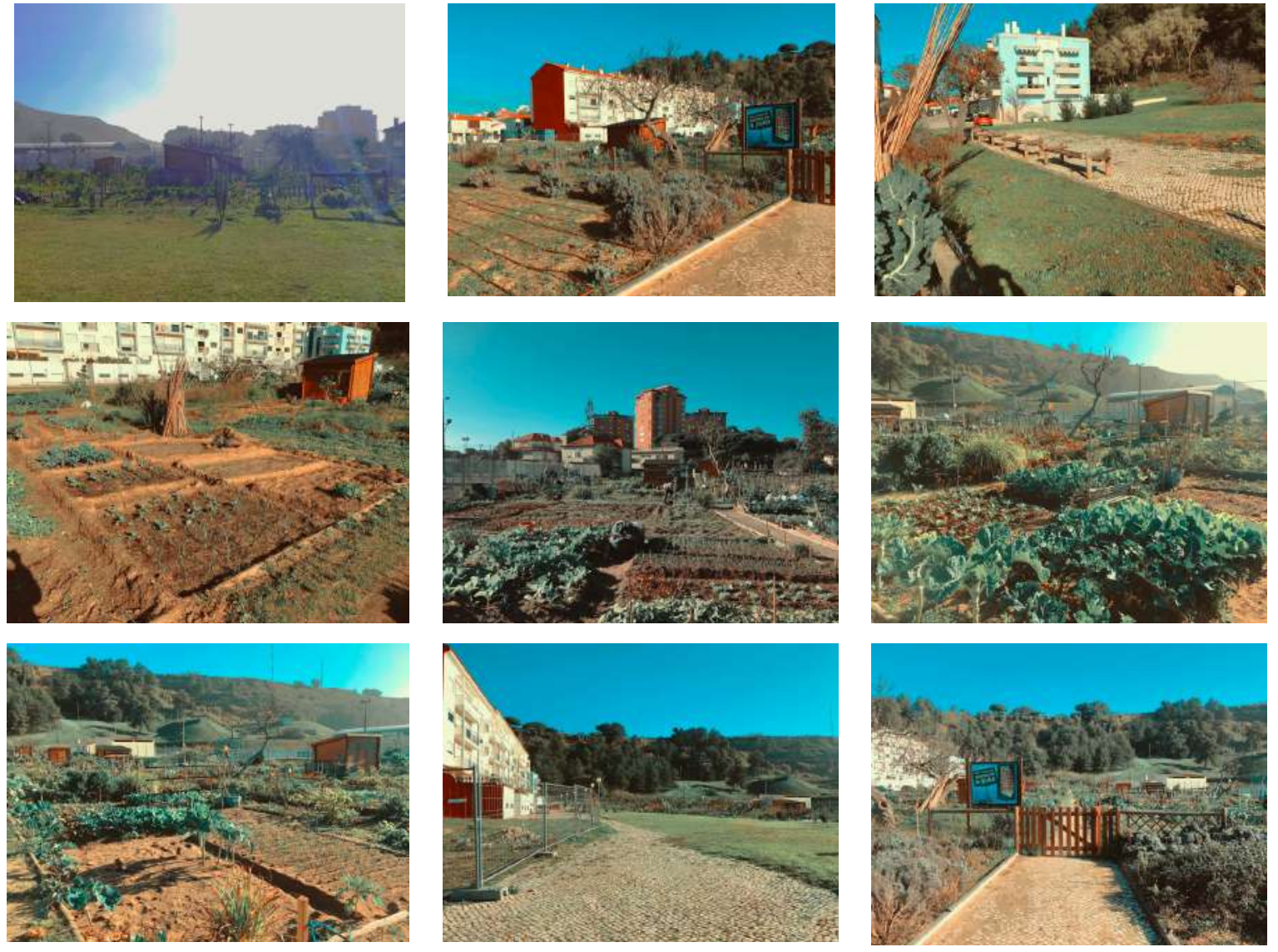

Figure 3 - The São João Municipal Allotments in Almada

\section{Discussion and concluding remarks}

Planning instruments in Portugal generally understand agricultural activities as being rural ones, an idea which underlies the regional and all municipal plans within the LMA. The casestudies which we have here showed are only three of numerous examples within the urban perimeters of the LMA, many of which have already been documented (Cabannes and Raposo, 2013; Oliveira et al, 2017; Delgado, 2018; Dias, 2018; Marat-Mendes et al, 2018). Municipal initiatives have created horticultural parks whose focus is predominantly based on a leisure dimension, but which still provide a contribution for the recovery of productive space within cities. In the case of the examples we have here detailed, the productive activities are taking place on land where, less than a century ago, was of agricultural or forestry use.

Guerrilla gardens distinguish themselves for more adaptive and individualized appropriation of space, but they seem to play a particularly important role on social housing neighbourhoods whose regeneration is acknowledged in the PDMs, but also in general by the PROT-AML (Cabannes and Raposo, 2013; Marat-Mendes and Borges, 2019). The examples of the Condado Estate and the Laveiras neighbourhood do both refer to council housing areas, and even if the Guerrilla Gardens are a direct response to a sense of urban isolation and poor access to food, they still denote how citizens appropriate available space and, in doing so, may contribute to the sustainability and productivity role of the territory. In these areas, knowledge and practices typically associated with the rural realm re-emerge in 
an urban context, changing the physical landscape. Furthermore, such knowledge and practices also change the social landscape, for they help inhabitants assessing their needs and struggling to be capable managers of urban space (Purcell and Tyman, 2015) and of the food system.

Such initiatives must also be acknowledged in terms of their environmental advantages, as they obviously bring people closer to the land and to the food production, a reality that has been long segregated from cities (Steel, 2008). They also help decrease dependency on the agri-food business and the access to fresh vegetables and fruit cultivated according to different knowledges (Cabannes and Raposo, 2013).

Urban agriculture examples must inform planning strategies, but more attention is needed to the productive dimension, rather than to the dominant leisure one, potential of it, as they bring advantages in terms of a more varied and food-secure city (Viljoen and Bohn, 2012). The existence of urban agriculture in the LMA, particularly considering the role of Guerrilla Gardens, must however be taken further, as a unique opportunity to conceive new conceptual frameworks that allow planning to come closer to societal demands (Webb et al, 2017).

In the LMA, there are several aspects of planning that can be changed towards a more sustainable model. In terms of metropolitan organization, the PROT-AML envisions a polycentric metropolitan area with compact centres. Agricultural and forestry activities are included in a Metropolitan Environmental Protection Structure, which despite its complexity presents no challenge to the urban-rural divide in most municipal plans - at the time and now. And while it proposes multimodal transportation systems, efforts are mostly directed at automobility.

Thus, despite its briefly stated commitment to sustainability, the PROT-AML seeks to develop the territory without calling into question the very opposition between urban and rural land. This however assumes an horizontal metabolism, with biomass entering urban perimeters from outside and with no use for waste agricultural activities. Our literature review (particularly Steel, 2008; Viljoen and Bohn, 2012; Reisch et al, 2013; Parham, 2016) would further suggest that a more sustainable approach (social and ecological one) would be indeed needed for cities to shorten their food systems and for production activities to move closer to urban areas, closing the gap between urban and rural. But so, would the three case-studies have described above. All are located in different contexts within the PROT while the Chelas Valley is considered a critical urban area, both Oeiras and Almada are mover spaces of the region, indeed closer to the centre. Yet, the interest in urban agriculture in these three municipalities attest to an important degree of demand on the part of population who either rent an allotment from the municipality or create one for their own.

At the municipal level, a greater recognition is still needed for urban agriculture. Although many municipalities have advanced horticulture gardens programs, solutions are needed in terms of a greater variety of urban design solutions and land-use policy to optimize them and make more allotments available, but also to understand the role of Guerrilla Gardens play within specific urban areas. In isolated council housing neighbourhoods, they show a constructive approach from local communities to make better use of available space, while improving their own access to quality food. Policy on this subject must beware of the dubious implications of charging the urban poor with their own food security while 
recognizing the contribution of urban agriculture to the sustainability of the territory by countering urbanization excess and adding new functionalities to specific areas.

There seems to be a gap between the aims and of Portuguese spatial planning instruments and some aspects of societal demand in the territory of the LMA. While PDMs and the PROTAML all acknowledge the need for sustainable development, this seems to be only possible within a set of a-priori conditions. These include the maintenance of the urban-rural divide, by increasing density in already urbanized areas and controlling growth in rural peripheries who concentrate the majority of food-production activities. By finding ways to include foodproduction in urban perimeters, spatial planning would not only be responding to a societal demand, but also taking one step further into shortening the metropolitan food-supply chain, thus improving its social-ecological metabolism.

\section{References}

Bartlett, Jamie (2017) Radicals Chasing Utopia - inside the rogue movements trying to change the world, New York, Nation Books.

Brinkley, Catherine (2013) "Avenues into food planning: a review of scholarly food system research", International Planning Studies, Vol.18 No.2, 243-266.

Cabannes, Yves, and Isabel Raposo (2013) "Peri-urban agriculture, social inclusion of migrant population and Right to the City - Practices in Lisbon and London", City, Vol.17 No.29, 235-250.

Cohen, Nevin; llieva, Rositsa T. (2015) "Transitioning the food system: a strategic practice management approach for cities", Environmental Innovation and Societal Transitions, Vol.17, 199-217.

Delgado, Cecília (2018) "Contrasting practices and perceptions of urban agriculture in Portugal", International Journal of Urban Sustainable Development Vol.10 No.2: 170-185.

Dias, Ana M. (2018) The shape of food - an analysis of urban agricultural shapes in Lisbon's Greater Area, Unpublished MSc Thesis, Instituto Universitário de Lisboa - ISCTE, Portugal.

DGT - Direç̧ão Geral do Território (2002) Plano Regional de Ordenamento do Território Área Metropolitana de Lisboa PPROT-AML, Versão editada. In http://www.ccdrIvt.pt/files/81360af5709e3ee6dc2e5860fd0869ff.pdf

Drago, Ana (2018) "This is what the democratic city is like: local democracy, housing rights and homeownership in the Portuguese constitutional debate", International Journal of Urban and Regional Research, Vol.41 No.3, 426-442.

Erb, Karl-Heinz; Fetzel, Tamara; Haberl, Helmut; Kastner, Thomas; Kroisleitner, Christine; Lauk, Christian; Niedertscheider, Maria; Ptutzar, Christoph (2016) "Beyond inputs and outputs: opening the black-box of land-use intensity", In Haberl, H.; FischerKowalski, M.; Krausmann, F.; Winiwarter, V. (eds). Social ecology - society-nature relations across time and space, Switzerlans, Springer, 93-124. 
Fischer-Kowalski, Marina; Haas, Willi (2014) "Exploring the transformation of human labour in relation to socio-ecological transitions", In Beblavý, M; Maselli, I.; Veselková, M (eds) Let's get to work! The future of labour in Europe - vol.1, Brussels, Centre for European Policy Studies, 56-84.

Fischer-Kowalski, Marina, and Weisz, Helga (2016) "The Archipelago of Social Ecology and the Island of the Vienna School", In Haberl, H.; Fischer-Kowalski, M.; Krausmann, F.; Winiwarter, V. (eds) Social Ecology, Switzerland, Springer, 3-28.

Heitor, Teresa Valsassina (2001) A vulnerabilidade do espaço em Chelas, Lisbon, Gulbenkian.

Howard, Ebenezer. 1902. Garden cities of to-morrow. London: Swan Sonnenschein.

Krausmann, Fridolin; Weisz, Helga; Eisenmenger, Nina (2016). "Transitions in sociometabolic regimes throughout human history", H. Haberl, M. Fischer-Kowalski, F. Krausmann, V. Winiwarter (eds) Social Ecology, Switzerland: Springer.

Lo, Alex Y. (2016) "Small is green? Urban form and sustainable consumption in selected OECD metropolitan areas", Land Use Policy, Vol.54, 212-220.

Marat-Mendes, Teresa (2009) "O PUCS e os vazios planeados. Novas oportunidades para o ordenamento sustentado da Costa do Sol". In Margarida Pereira (ed) O Plano de Urbanização da Costa do Sol - Uma visão inovadora para o território, Oeiras, Câmara Municipal de Oeiras, 92-122.

Marat-Mendes, Teresa (coord), Mourão, Joana; Bento d’Almeida, Patrícia; Niza, Samuel (2015). Water and Agriculture Atlas: Lisbon Region in 1900-1940, Lisbon, Instituto Universitário de Lisboa - ISCTE/ DINAMIA'CET-IUL.

Marat-Mendes, Teresa; Borges, João Cunha; Dias, Ana Mélice; Lopes, Raul (2018), Food system and Spatial Municipal Planning - analysis of its integration in the 18 municipalities of the Lisbon Metropolitan Area', presentation at Dinâmicas socioeconómicas e territoriais contemporâneas IV - ISCTE, Lisbon, December $17^{\text {th }}$.

Marat-Mendes, Teresa; Borges, João Cunha (2019). The urban planning transition history of the Lisbon Metropolitan Area, Proceedings of ASEOP 2019 Congress, Venice, July $10^{\text {th }}$.

Moudon, Anne V., Adam Drewnowski, Glen E. Duncan, Philip M. Hurvitz, Brian E. Saelens and Eric Scharnhorst (2013) "Characterizing the food environment: pitfalls and future directions", Public Health Nutr Vol.16 No.7, 1238-43.

Mourão, Joana, and Marat-Mendes, Teresa (2016) "Urban planning and territorial management in Portugal - Antecedents and impacts of the 2008 financial and economic crisis." In Jörg Knieling and Frank Othengraffen (eds) Cities in Crisis Socio-Spatial Impacts of the Economic Crisis in Southern European Countries, London, Routledge, 157-171.

Niza, Samuel (2017) " O sistema alimentar no contexto do metabolismo urbano da Área Metropolitana de Lisboa", In Oliveira, R.; Amâncio, S.; Fadigas, L. (eds) Alfaces na avenida. Estratégias para (bem) alimentar a cidade, Lisbon, Universidade de Lisboa, Colégio Food, Farming and Forest, 42-47. 
Niza, Samuel; Ferreira, Daniela; Mourão, Joana; Bento d’Almeida, Patrícia; Marat-Mendes, Teresa (2016) "Lisbon's womb: an approach to the city metabolism in the turn to the twentieth century", Regional Environmental Change Vol.16 No.6, 1725-1737.

Oliveira, Rosário; Amâncio, Sara; Fadigas, Leonel (eds) (2017) Alfaces na avenida. Estratégias para (bem) alimentar a cidade, Lisbon, Universidade de Lisboa, Colégio Food, Farming and Forest.

Parham, Susan (2016) Food and urbanism - the convivial city and a sustainable future, London, Bloomsbury.

Pereira, Margarida (2009) "O Plano de Urbanização da Costa do Sol - o pioneirismo de um plano sub-regional" In Margarida Pereira (ed) O Plano de Urbanização da Costa do Sol - Uma visão inovadora para o território, Oeiras, Câmara Municipal de Oeiras, 2441.

Pothukuchi, Kamershwari; Kaufman, Jerome L. (2000) "The food system - a stranger in the planning field", Journal of the American Planning Association, Vol.66, No.2, 113-124.

Purcell, Mark, and Shannon Tyman (2015) "Cultivating food as a right to the city", Local Environment Vol.20 No.10, 1132-1147.

Reisch, Lucia; Eberle, Ulrike; Lorek, Sylvia (2013) "Sustainable food consumption: an overview of contemporary issues and policies", Sustainability: Science, Practice and Policy, Vol.9, No.2, 7-25.

Reynolds, Richard (2008) On Guerrilla Gardening - A Handbook for Gardening Without Boundaries, London, Bloomsbury.

Rogers, Richard (1997) Cities for a small planet, London, Basic Books.

Sonnino, Roberta (2019) "The cultural dynamics of urban food governance", City, Culture \& Society, Vol.16, 12-17.

Steel, Carolyn (2013 [2008]) Hungry City - how food shapes our lives, London, Vintage Books.

United Nations. 2015. The 2030 Agenda for Sustainable Development http://www.un.org/ga/search/view doc.asp?symbol=A/RES/70/1\&Lang=E (Accessed 21-01-2019).

United Nations. 2016. Habitat III - New Urban Agenda - http://habitat3.org/wpcontent/uploads/NUA-English.pdf (Accessed 21-01-2019).

Viljoen, André; Bohn, Katrin (2012) "Planning and designing food systems, moving to the physical", In Viljoen, A.; Wiskerke, J.C.S. (eds) Sustainable food planning: evolving theory and practice, Gelderland, Wageningen Academics.

Webb, R.; Bai, X.; Smith, M.S.; Costanza, R.; Griggs, D.; Moglia, M.; Neuman, M.; Newman, P.; Newton, P.; Norman, B.; Ryan, C.; Schandl, H.; Steffen, W.; Tapper, N.; Thomson, G. (2017) "Sustainable urban systems: Co-design and framing for transformation", Ambio, Vol.47, 57-77.

Wekerle, Gerda R. and Classens, Michael (2015) "Food production in the city: (re)negotiating land, food and property", Local Environment Vol.20 No.10, 1175-1193. 
Winiwarter, Verena; Schmid, Martin; Haberl, Helmut; Singh, Simron (2016) " Why legacies matter: merits of a long-term perspective", In Haberl, H.; Fischer-Kowalski, M.; Krausmann, F.; Winiwarter, V. (eds) Social Ecology, Switzerland, Springer.

Wolman, Abel (1965) The metabolism of cities. Scientific American, Vol.213 No.3, 179-190. 